Published in final edited form as:

Chentsova, A., Ushakov, D. B., Seeberger, P. H., \& Gilmore, K. (2016). Synthesis of $\alpha$-nitro carbonyls via nitrations in flow. The Journal of Organic Chemistry, 81(19), 9415-9421. doi:10.1021/ acs.joc.6b01634.

\title{
Synthesis of $\alpha$-nitro carbonyls via nitrations in flow
}

\author{
Anna Chentsova, Dmitry Ushakov, Peter H. Seeberger, Kerry Gilmore
}<smiles>[R3]OC(=O)C([R2])NOC([R3])C([R2])O[R6]</smiles> 


\title{
Synthesis of $\alpha$-Nitro Carbonyls via Nitrations in Flow
}

\author{
Anna Chentsova ${ }^{\dagger,}$, Dmitry B. Ushakov ${ }^{t, \S}$, Peter H. Seeberger ${ }^{t, \ddagger}$, and Kerry Gilmore \\ *十. \\ † Department of Biomolecular Systems, Max-Planck-Institute of Colloids and Interfaces, Am \\ Mühlenberg 1, 14476 Potsdam, Germany \\ ‡ Freie Universität Berlin, Institute of Chemistry and Biochemistry, Arnimallee 22, 14195 Berlin, \\ Germany
}

Corresponding Author

*E-mail: kerry.gilmore@mpikg.mpg.de

$\S$ These authors contributed equally to this work

\section{ABSTRACT}

Reported is a safe, rapid method for the synthesis of a-nitro esters, via the trapping of nitronium ions. The two-stage nitration and subsequent deacetylation of readily available 1,3-dicarbonyl compounds was achieved using a biphasic semi-continuous approach. $\alpha-N i t r o$ esters and amides were obtained in good overall yields (53-84\%). Some of the a-nitro-1,3-dicarbonyl intermediates exhibit enhanced reactivity and undergo an acid-catalyzed Nef-type reaction to a-oxo-carbonyls.

a-Nitro esters are valuable synthons in organic synthesis, ${ }^{1}$ that can, due to their 1,3 -dipole nature and the high acidity of the a-proton (pKa $\sim 5.8$ ), be further transformed in a variety of ways. ${ }^{2}$ They serve as carbon nucleophiles ${ }^{3}$ and dipoles for heterocycle synthesis; ${ }^{1,4}$ they can form phenyliodonium or diazo ylide derivatives, ${ }^{5}$ the latter of which can participate in $\mathrm{NH}$ insertion/Mannich-type reactions. ${ }^{6}$ Moreover, $\alpha$-nitro esters are intermediates for the synthesis of $\alpha$-keto esters, ${ }^{7} \gamma$-oxo acids, ${ }^{3 f}$ as well $\alpha$ amino acids. ${ }^{5 c, 7-8}$

Retrosynthetically, the a-nitro ester moiety offers two main disconnections (Scheme 1). The functionalization of a nitroalkane with a $\mathrm{CO}_{2}$ synthon, ${ }^{9}$ is less common. One means of producing the unsubstituted $\alpha$-nitro ester is the self-condensation of nitromethane under harsh basic conditions 
followed by an acid-catalyzed esterification. ${ }^{10}$ Further alkylations or arylations of this core are possible. ${ }^{8 c, 11}$

More commonly, C-N bond formation is the key reaction. The nitro group can be introduced in either a nucleophilic or electrophilic manner. The most direct approach involves the treatment of $\alpha$-haloesters with a nitrite anion. ${ }^{12}$ However, the substrate scope of this route is limited ${ }^{12 a, 13}$ and scavengers are required to avoid the formation of a-oximinoesters. ${ }^{12 b, 14}$ Side product formation can be avoided through a two-step process, transforming $\alpha$-haloesters via the corresponding $\alpha$-azidoester (Scheme 1). The desired nitro derivatives are then generated under strong oxidizing conditions $\left(\mathrm{HOF} \cdot \mathrm{CH}_{3} \mathrm{CN}\right)$, rendering this approach less amenable to sensitive substrates such as olefins and amines. ${ }^{15}$

Scheme 1. Synthetic approaches for the synthesis of $\alpha$-nitro esters.

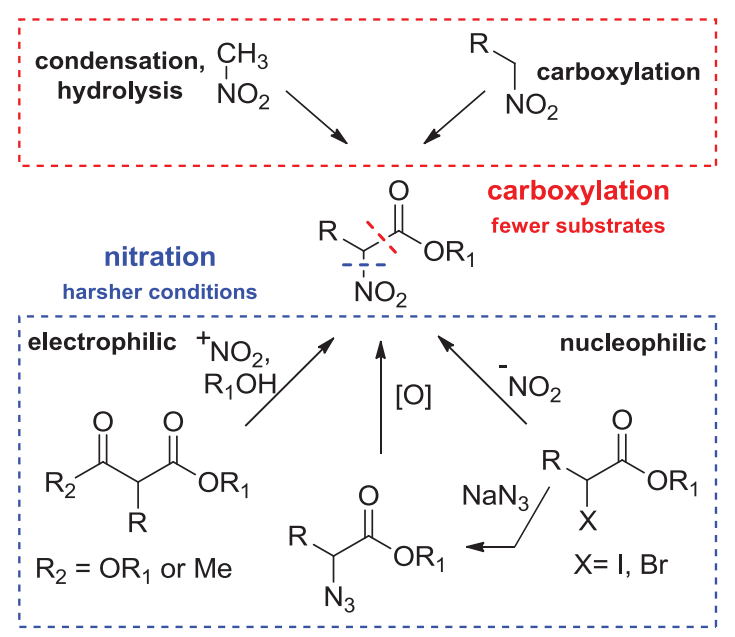

The umpolung approach, where an electrophilic nitronium ion is captured by an enolizable nucleophile, expands the potential pool of starting materials to $\beta$-keto esters. Early work by Sifniades provided a homogeneous path, generating the key electrophile intermediate using an acetic anhydride/nitric acid mixture. ${ }^{16}$ However, this approach is very temperature sensitive, resulting in side product formation and - disturbingly - the "ejection of the reaction mixture from the reaction vessel". ${ }^{17}$

Biphasic systems where a mixture of sulfuric acid and nitric acid (or $\mathrm{NH}_{4} \mathrm{NO}_{3}$ ) was added to a chloroform solution of an acetoester at reduced temperatures offered better control over the reaction conditions. ${ }^{17-18}$ The transformation requires vigorous stirring and careful temperature control over the one to three hours it takes to complete. The resulting a-nitroacetate ester derivative is efficiently deacylated to give the nitro ester. While there are few published examples for this process, ${ }^{16-19}$ continuous flow nitration of aromatic substrates has allowed for the safer handling of the corrosive 
strong acids, ${ }^{20}$ improved temperature control inside the reactor, ${ }^{21}$ and for the prevention of overnitration. ${ }^{22}$ In addition, biphasic reactions are significantly accelerated in flow due to the increased interfacial area between the phases. Precise control of the reaction conditions in meso-flow reactors should be a good basis for a general, safe, and broadly applicable process to generate valuable $\alpha$ nitro esters.

The first step of the nitration/deacylation process (Scheme 2) is electrophile generation. The controlled formation of a nitronium ion occurred rapidly in a $30 \mu \mathrm{L}$ PTFE (polytetrafluoroethylene) reactor at 10 ${ }^{\circ} \mathrm{C}$ upon mixing pre-cooled fuming nitric acid $\left(90+\%, 1.2\right.$ equiv., $\left.0.013 \mathrm{~mL} \mathrm{~min}^{-1}\right)$ and concentrated sulfuric acid $\left(96 \%, 6\right.$ equiv., $\left.0.080 \mathrm{~mL} \mathrm{~min}{ }^{-1}\right)$. After a $19 \mathrm{~s}$ residence time, the stream of $\alpha-$ acetylbutyrolactone (1) in $\mathrm{CH}_{2} \mathrm{Cl}_{2}\left(0.36 \mathrm{~m}, 0.663 \mathrm{~mL} \mathrm{~min}^{-1}\right)$ was introduced via a T-mixer. The biphasic solution then passed through a second PTFE reactor $\left(0.35 \mathrm{~mL}, 10^{\circ} \mathrm{C}\right.$, residence time $\left.28 \mathrm{~s}\right)$. The solution was quenched by addition of the exiting stream to a stirred suspension of $\mathrm{MgSO}_{4}$ in $\mathrm{CH}_{2} \mathrm{Cl}_{2}$ at room temperature. After completion of the reaction, the quenching agent was filtered off and the solvent removed under reduced pressure. Deacylation occurred by addition and subsequent evaporation of methanol. ${ }^{1} \mathrm{H}$ NMR analysis revealed the desired $\alpha$-nitrolactone 3 in $63 \%$ yield with $92 \%$ conversion (Table 1, entry 1).

Scheme 2. Semi-continuous setup for the nitration/deacylation of 1,3-dicarbonyl compounds.

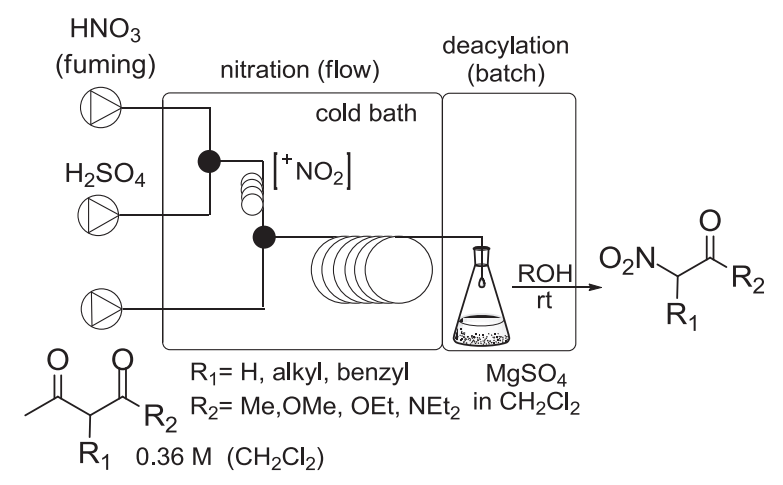


Table 1. Optimization of nitration/deacylation of $\alpha$-acetylbutyrolactone (1). ${ }^{a}$

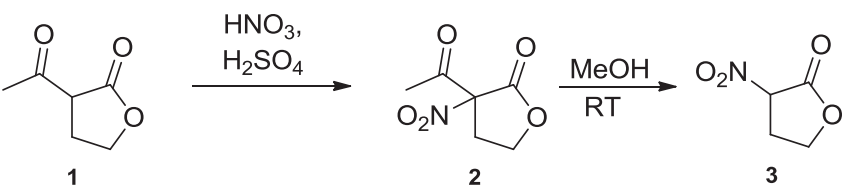

\begin{tabular}{ccccccc}
\hline Entry & $\begin{array}{c}\mathrm{HNO}_{3} \\
\text { equiv. }\end{array}$ & $\begin{array}{c}\mathrm{H}_{2} \mathrm{SO}_{4} \\
\text { equiv. }\end{array}$ & $\begin{array}{c}\text { Res. } \\
\text { time, } \\
(\mathrm{s})\end{array}$ & $\begin{array}{c}\mathrm{T} \\
\left({ }^{\circ} \mathrm{C}\right)\end{array}$ & $\begin{array}{c}\text { Conversion } \\
(\%)^{b}\end{array}$ & Yield $(\%)^{b}$ \\
\hline 1 & 1.2 & 6 & $28^{c}$ & 10 & 92 & 63 \\
2 & 1.2 & 6 & 48 & 10 & $>95$ & 70 \\
3 & 1.4 & 6 & 47 & 10 & $>95$ & 74 \\
4 & 1.4 & 4 & 49 & 10 & $>95$ & 70 \\
5 & 1.4 & 7.8 & 46 & 10 & $>95$ & 79 \\
6 & 1.4 & 10 & 44 & 10 & $>95$ & 74 \\
7 & $1.4^{d}$ & 6.1 & 47 & 5 & 76 & 60 \\
8 & 1.4 & 7.8 & 46 & 15 & $>95$ & 74 \\
9 & 1.4 & 7.8 & 46 & 5 & $>95$ & 75 \\
10 & 1.4 & 7.8 & 46 & 0 & $>95$ & 73 \\
11 & 1.4 & 7.8 & $54^{e}$ & 10 & $>95$ & $80(78 \%)^{t}$ \\
\hline
\end{tabular}

${ }^{a}$ Reaction conditions: $\alpha$-acetylbutyrolactone (1) in $\mathrm{CH}_{2} \mathrm{Cl}_{2}\left(0.36 \mathrm{M}, 0.66 \mathrm{~mL} \mathrm{~min}{ }^{-1}\right)$; reactor volume $0.6 \mathrm{~mL}, 96 \%$ $\mathrm{H}_{2} \mathrm{SO}_{4}$ and $90+\%$ fuming $\mathrm{HNO}_{3}$ were used unless indicated, equivalents with respect to $\alpha$-acetylbutyrolactone (1); quench: $5 \mathrm{~g} \mathrm{MgSO}_{4}$ in $20 \mathrm{~mL} \mathrm{CH} \mathrm{Cl}_{2}$, rt; deacylation via addition of $2 \mathrm{~mL}$ of methanol. ${ }^{b}$ Determined using mesitylene as internal standard; yield over two steps. ${ }^{c}$ Reactor volume $0.35 \mathrm{~mL} .{ }^{d} 65 \%$ Nitric acid. ${ }^{e}$ Reactor volume $0.7 \mathrm{~mL} .{ }^{f}$ Isolated yield in parentheses.

Both an increase in the residence time using a larger second reactor $(0.6 \mathrm{~mL}$, entry 2$)$ as well as the equivalents of nitric acid (entry 3 ) resulted in higher yields with complete conversion. While decreasing amounts of sulfuric acid did not improve the yield (70\%, entry 4), an increase to 7.8 equivalents (entry 5) afforded the desired compound in $79 \%$. Further changes were not advantageous (entry 6 ). Use of more dilute nitric acid (65\%) resulted in the drop in both conversion and yield (entry 7$)$. After additional temperature screenings (entries 8-10), 1.4 equiv. nitric acid and 7.8 equiv. sulfuric acid at $10{ }^{\circ} \mathrm{C}$ were found to be optimal with an overall residence time of 54 seconds for the nitration (entry 11). The reaction was efficiently quenched with $1 \mathrm{~g} \mathrm{MgSO}_{4}$ per $1 \mathrm{~mL}$ acid solution. ${ }^{23}$ The productivity of this process, following off-line deacylation, is $1.47 \mathrm{~g} /$ hour of the desired 3-nitrodihydrofuran-2(3H)-one (3).

The optimized reaction conditions were tested on a range of 1,3-dicarbonyl compounds (Table 2). a-Substituted acetoacetates bearing an additional ester group gave the corresponding $\alpha$-nitro esters in good yields (entries 1-2). Alkyl substituted substrates gave moderate [entries $3(59 \%), 4$ (53\%)] to 
good yields (entry $5,82 \%$ ), with the $n B$ chain requiring slightly higher amounts of acid to achieve full conversion (entry 6,72\%). Electron-withdrawing groups hinder the reaction, with ethyl 2-chloro-3oxobutanoate (16) necessitating higher temperature $\left(20^{\circ} \mathrm{C}\right)$, a longer reaction time (107 s), and approximately twice as much acid (substrate: $0.2 \mathrm{M}$, entry 7 ). ${ }^{24}$

Table 2. Nitration/deacylation of 1,3-dicarbonyl compounds in a semi-continuous flow system. ${ }^{a}$

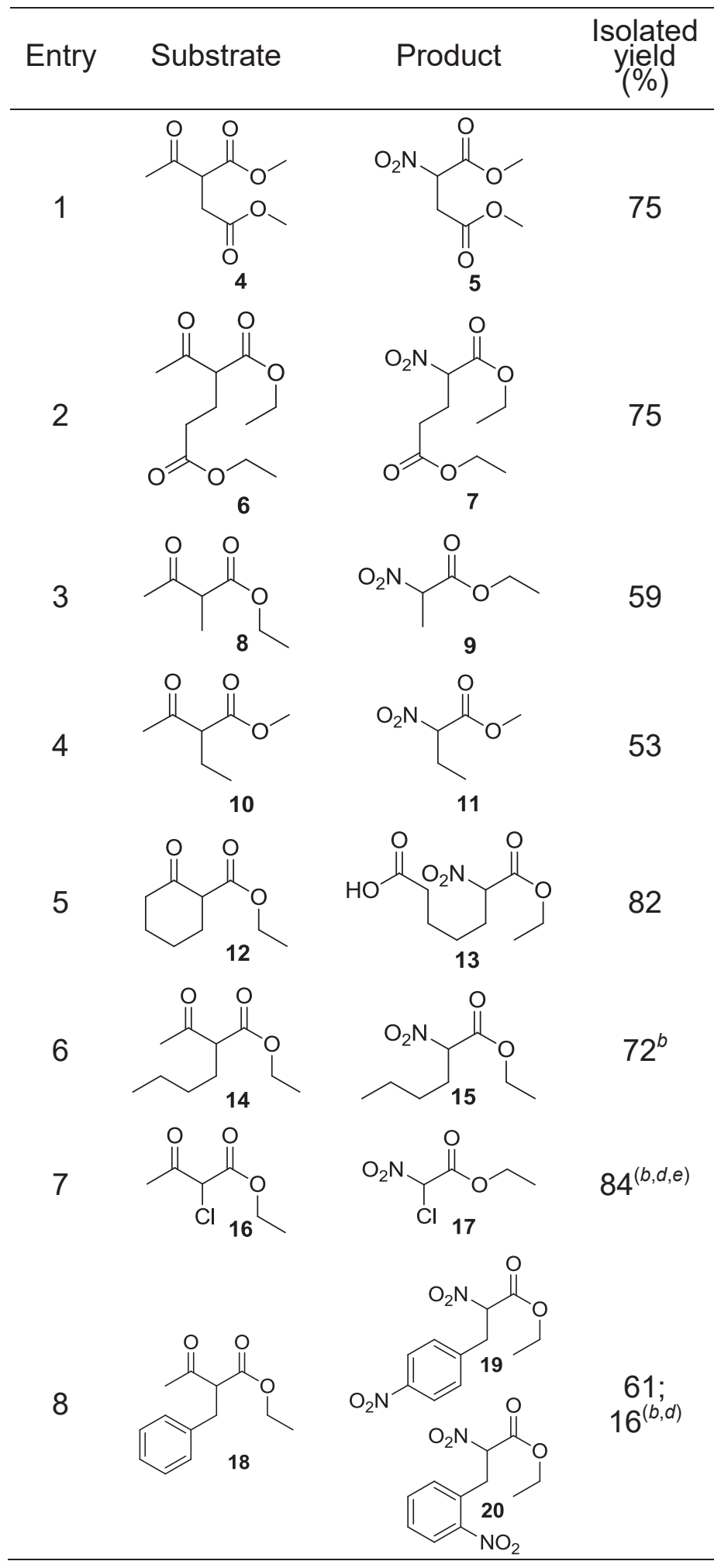


9<smiles>CCOC(=O)CC(C)=O</smiles>

21

10<smiles>CCN([13CH3])C(=O)CC(C)=O</smiles>

11

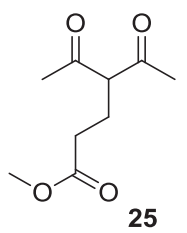

12

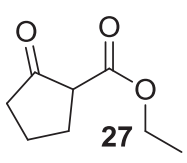

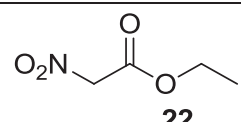

22
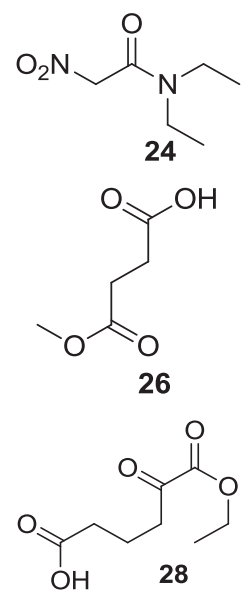

$70^{(c)}$

$54^{(b, f)}$

34

$61^{(d)}$

\footnotetext{
${ }^{a}$ Standard nitration conditions: $0.36 \mathrm{M}$ solution in $\mathrm{CH}_{2} \mathrm{Cl}_{2}\left(0.663 \mathrm{~mL} \mathrm{~min}{ }^{-1}\right) ; 10^{\circ} \mathrm{C}$; residence time $54 \mathrm{~s}$; $\mathrm{HNO}_{3}$ $\left(90+\%, 0.016 \mathrm{~mL} \mathrm{~min}{ }^{-1}\right), \mathrm{H}_{2} \mathrm{SO}_{4}\left(96 \%, 0.103 \mathrm{~mL} \mathrm{~min}{ }^{-1}\right)$; for quenching and deacylation procedure see Experimental Section. Yield determined over two steps. ${ }^{b}$ Higher amounts of acids used for complete conversion, see Experimental Section. ${ }^{c} 1 \mathrm{M}$ solution in $\mathrm{CH}_{2} \mathrm{Cl}_{2}\left(0.4 \mathrm{~mL} \mathrm{~min}{ }^{-1}\right),-5$ to $-3{ }^{\circ} \mathrm{C}$; residence time $200 \mathrm{~s} ; \mathrm{HNO}_{3}(65 \%$, $\left.0.031 \mathrm{~mL} \mathrm{~min}{ }^{-1}\right), \mathrm{H}_{2} \mathrm{SO}_{4}\left(96 \%, 0.110 \mathrm{~mL} \mathrm{~min}^{-1}\right) .{ }^{d}$ Determined by NMR using mesitylene as internal standard; ${ }^{e}$ Residence time $107 \mathrm{~s}, 20^{\circ} \mathrm{C}$. ${ }^{f}$ Residence time $107 \mathrm{~s}$.
}

Several substrates suffer from competing reactions. Ethyl 2-benzylacetoacetate (18, entry 8 ) can also undergo electrophilic aromatic substitution, and the previously optimized conditions resulted in only $71 \%$ conversion with multiple substituted products. The reaction was pushed to completion by increasing the equivalents of acid (substrate: $0.16 \mathrm{M}$ ). The double nitrated scaffolds $19(61 \%)$ and 20 $(16 \%)$ were identified as the main products. This represents a limitation of the method, as nitration is believed to occur first at the aromatic ring due to the observation of the solely aryl-nitrated ethyl 2-(4nitrobenzyl)-3-oxobutanoate (7\%).

In the case of $\alpha$-unsubstituted ethyl acetoacetate $\mathbf{2 1}$, two competing pathways following nitration can occur due to the additional acidic proton: dimerization, which affords a substituted furoxan, ${ }^{17}$ and dinitration of the a-position. These pathways could be partly suppressed using a more dilute nitronium ion solution (65\% nitric acid) and a larger second reactor $(1.8 \mathrm{~mL})$, providing the desired ethyl 2nitroacetate 22 in $70 \%$ yield (entry 9 ). ${ }^{25}$

Under the reaction conditions, several a-nitro acyl compounds exhibit enhanced reactivity resulting in the formation of different functional groups. Nitration of $\mathrm{N}, \mathrm{N}$-diethyl-3-oxobutanamide 23 gave a moderate yield of the $\alpha$-nitro amide (entry 10,54\%) after a longer reaction time (107 s) and a change 
in the equivalents of nitronium ion (substrate: $0.2 \mathrm{M}$ ). One explanation for the lower yield is the formation, post-nitration, of two side products; one resulting from the in situ deacylation and dehydration of the nitro group (see Experimental Section for details).

No a-nitro product was observed for the 1,3-diacyl analog methyl 4-acetyl-5-oxohexanoate (25, entry 11). 4-Methoxy-4-oxobutanoic acid 26 was isolated as major product (34\%). The formation of the carboxylic acid is not surprising as an in situ deacylation would result in the formation of a secondary a-nitro ketone, which is known to undergo fragmentation under strong acidic conditions to give the corresponding carboxylic acid. ${ }^{26}$ The a-nitro ketone intermediate can also undergo a Nef reaction, as indicated by the isolation of small amounts both $\alpha$-oxime- and $\alpha$-oxo-ketone from the same reaction mixture. $^{27}$

Unexpectedly, this acid-catalyzed Nef reaction - which generally requires a nitronate intermediate becomes the predominant pathway for ethyl 2-oxocyclopentanecarboxylate 27. Compared to lactone 1, where the $\alpha$-nitro-y-lactone is obtained in high yield, the cyclopentanone ester provides $\alpha$-oxo-ester 28 in $61 \%$ yield (entry 12). This result can be explained assuming the formation of the protonated acinitro species $\mathbf{3 0}$ under strong acidic conditions, followed by a Nef reaction to give $\alpha$-oxo-product 28 and oxime 31 - the latter of which was isolated in 5\% yield (Scheme 3 ) and whose formation is known to be dependent on the $\mathrm{pH}$ of the reaction medium. ${ }^{28}$

Scheme 3. Proposed pathway for the formation of 6-ethoxy-5,6-dioxohexanoic acid (28) and oxime 31. ${ }^{a}$ NMR yield using mesitylene as internal standard ( $47 \%$ isolated yield).

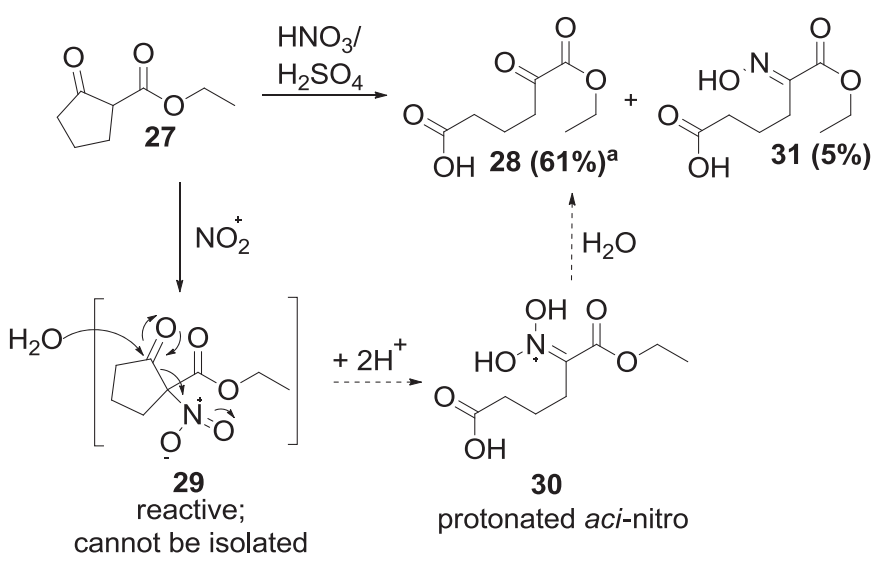

In conclusion, a rapid, facile, and safe procedure for the a-nitration of 1,3-dicarbonyls via a two-step nitration and deacylation process is disclosed. The controlled nitration in a continuous flow reactor occurs rapidly (54-200 s). Following the quenching of excess $\mathrm{H}_{2} \mathrm{SO}_{4} / \mathrm{HNO}_{3}$ using $\mathrm{MgSO}_{4}$, deacylation 
is achieved in methanol/ethanol in batch. A range of a-nitro esters/amides were produced with moderate-to-good yields (53-84\%). Some a-nitro-1,3-dicarbonyl intermediates exhibit enhanced reactivity and under the reaction conditions yielding either Nef $\alpha$-oxo products or carboxylic acids.

\section{Experimental Section}

General Information. All commercially available compounds and solvents were used without purification. Sulfuric acid (96\%) and fuming nitric acid (90+\%) were purchased from Roth (ROTIPURAN®, 4623.4) and Acros (ACS reagent, A0332793) respectively. Acids and substrates were delivered into the reactor with the help of individual syringe pumps. Both flow reactors were built using polytetrafluoroethylene (PTFE) tubing $(1.59 \mathrm{~mm}$ outer diameter, $0.76 \mathrm{~mm}$ inner diameter) and connected by ethylene tetrafluoroethylene (ETFE) T-mixers. All tubing, connectors and adapters were purchased from IDEX Health and Science. All tubing and mixers were immersed in a water bath, cooled with the help of immersion cooler. Column chromatography was performed using MachereyNagel silica gel $60 \mathrm{M}(0.04-0.063 \mathrm{~mm})$. Preparative HPLC was performed using a semi-preparative YMC-Pack Diol-300-NP column (150 x $20 \mathrm{~mm})$. The compounds were visualized by UV (254 nm) and by staining with an aqueous solution of potassium permanganate (prepared from $1.5 \mathrm{~g} \mathrm{KMnO}_{4}$ and 10 $\mathrm{g} \mathrm{K}_{2} \mathrm{CO}_{3}$ in $1.25 \mathrm{~mL} 10 \% \mathrm{NaOH}$ in $200 \mathrm{~mL}$ water). In describing ${ }^{1} \mathrm{H}$ and ${ }^{13} \mathrm{C}$ NMR spectra the following abbreviations were used to define the multiplicities $(s=$ singlet, $d=$ doublet, $d d=$ doublet of doublets, $\mathrm{ddd}=$ doublet of doublet of doublets, $\mathrm{t}=$ triplet, $\mathrm{dq}=$ doublet of quartets, $\mathrm{m}=$ multiplet, $\mathrm{br}=\mathrm{broad}$ ), with coupling constants $(J)$ in Hertz $(\mathrm{Hz})$ and integration. Chemical shifts are reported in parts per million $(\mathrm{ppm})$ relative to residual solvent peaks $(\delta)$ and are calibrated to the residual proton and carbon resonance of $\mathrm{CDCl}_{3}\left({ }^{1} \mathrm{H}: 7.24,{ }^{13} \mathrm{C}: 77.16\right), \mathrm{CD}_{3} \mathrm{OD}\left({ }^{1} \mathrm{H}: 3.31,{ }^{13} \mathrm{C}: 49.00\right) .{ }^{29}$ High resolution mass spectra were obtained using ESI-Q-TOFmicro mass spectrometer and ESI-TOF mass spectrometer.

General procedure for nitration and deacylation step. Fuming nitric acid $(90+\%, 16 \mu \mathrm{L}$ $\left.\mathrm{min}^{-1}, 0.343 \mathrm{mmol} / \mathrm{min}\right)$ was mixed with sulfuric acid $\left(96 \%, 103 \mu \mathrm{L} \mathrm{min}^{-1}, 1.85 \mathrm{mmol} / \mathrm{min}\right)$ at $10^{\circ} \mathrm{C}$ (cooling bath was used) using a T-mixer. The resulting flow stream was passed through a $0.03 \mathrm{~mL}$ PTFE-tubing ( $0.76 \mathrm{~mm}$ inner diameter) and mixed with the solution of the $\alpha$-acetyl compound (0.36 $\mathrm{M}$ in $\mathrm{CH}_{2} \mathrm{Cl}_{2}, 0.663 \mathrm{~mL} \mathrm{~min}{ }^{-1}, 0.239 \mathrm{mmol} / \mathrm{min}$ ) using second T-mixer at the same temperature. The biphasic mixture was then passed through a $0.7 \mathrm{~mL}$ PTFE-tubing and collected in an Erlenmeyer flask containing a stirred suspension of $\mathrm{MgSO}_{4}(5-10 \mathrm{~g})$ in $\mathrm{CH}_{2} \mathrm{Cl}_{2}(20 \mathrm{~mL})$ at room temperature. $\mathrm{MgSO}_{4}$ 
was filtered of and the reaction mixture was concentrated under reduced pressure. If deacylation does not occur in situ, the following procedure was performed: the residue was dissolved in $30 \mathrm{~mL}$ of the corresponding alcohol $(\mathrm{EtOH} / \mathrm{MeOH})$ and stirred from $2 \mathrm{~h}$ to overnight (temperature varies from room temperature to reflux depending on the substrate). After completion of the reaction the solvent was removed under reduced pressure and the residue was purified by column chromatography.

3-Nitrodihydrofuran-2(3H)-one (3): General nitration procedure was used (0.6 mL (5.58 mmol) of $\alpha$ acetylbutyrolactone (1) in $\left.\mathrm{CH}_{2} \mathrm{Cl}_{2}(15 \mathrm{~mL})\right)$. Quenching and deacylation procedure: for $11 \mathrm{~mL}$ of the collected solution $5 \mathrm{~g}$ of $\mathrm{MgSO}_{4}$ and $20 \mathrm{~mL} \mathrm{CH} \mathrm{Cl}_{2}$ were used. The reaction mixture was filtered, treated with $\mathrm{MeOH}(2 \mathrm{~mL})$ and concentrated under reduced pressure $\left(30^{\circ} \mathrm{C}\right)$. The residue was purified by column chromatography ( $n$-hexane/ethyl acetate $25: 1 \rightarrow 9: 1 \mathrm{v} / \mathrm{v}$ ) to give compound 3 (405 mg, $78 \%)$ as a orange oil. $\mathrm{R}_{\mathrm{f}}=0.16(n$-hexane/ethyl acetate $=3: 2 \mathrm{v} / \mathrm{v}) ;{ }^{1} \mathrm{H}$ NMR $\left(400 \mathrm{MHz}, \mathrm{CDCl}_{3}\right): 2.82$ (dddd, $\mathrm{J}=14.0,9.0,7.4,4.8 \mathrm{~Hz}, 1 \mathrm{H}$ ), 2.96 (dddd, $\mathrm{J}=14.4,8.5,7.3,7.3 \mathrm{~Hz}, 1 \mathrm{H}$ ), 4.38 (ddd, $\mathrm{J}=9.2$, 7.3, $7.3 \mathrm{~Hz}, 1 \mathrm{H}), 4.56(\mathrm{ddd}, \mathrm{J}=8.8,4.9,4.9 \mathrm{~Hz}, 1 \mathrm{H}), 5.38(\mathrm{dd}, \mathrm{J}=9.0,7.4 \mathrm{~Hz}, 1 \mathrm{H}) ;{ }^{13} \mathrm{C}$ NMR $(100$ $\left.\mathrm{MHz}, \mathrm{CDCl}_{3}\right): 27.9,66.9,82.2,167.2$; HRMS (ESI): $[\mathrm{M}+\mathrm{Na}]^{+}$calcd for $\mathrm{C}_{4} \mathrm{H}_{5} \mathrm{NO}_{4} \mathrm{Na}: 154.0116$, found 154.0106, $[\mathrm{M}+\mathrm{K}]^{+}$calcd for $\mathrm{C}_{4} \mathrm{H}_{5} \mathrm{NO}_{4} \mathrm{~K}: 169.9856$ found 169.9845 .

Dimethyl 2-nitrosuccinate (5): General nitration procedure was used (0.82 $\mathrm{mL}$ (5.05 mmol) of dimethyl 2-acetylsuccinate (4) in $\left.\mathrm{CH}_{2} \mathrm{Cl}_{2}(13.2 \mathrm{~mL})\right)$. Quenching and deacylation procedure: for $11 \mathrm{~mL}$ of the collected solution $5 \mathrm{~g}$ of $\mathrm{MgSO}_{4}$ and $20 \mathrm{~mL} \mathrm{CH} \mathrm{Cl}_{2}$ were used, the reaction mixture was filtered and concentrated under reduced pressure. The residue was dissolved in $30 \mathrm{~mL} \mathrm{MeOH}$ and stirred overnight at room temperature. The solvent was removed under reduced pressure and the residue was purified by column chromatography ( $n$-hexane $\rightarrow n$-hexane/ethyl acetate, 100:0 $\rightarrow 9: 1 \mathrm{v} / \mathrm{v}$ ) to give compound 5 (569 mg, 75\%) as a yellow oil. $R_{f}=0.49$ ( $n$-hexane/ethyl acetate $\left.=5: 1 \mathrm{v} / \mathrm{v}\right) ;{ }^{1} \mathrm{H}$ spectrum matches with the literature data. ${ }^{30}{ }^{1} \mathrm{H}$ NMR $\left(400 \mathrm{MHz}, \mathrm{CDCl}_{3}\right): 3.16(\mathrm{dd}, \mathrm{J}=17.7,4.9 \mathrm{~Hz}, 1 \mathrm{H}) ; 3.38$ (dd, $J=17.7,9.2 \mathrm{~Hz}, 1 \mathrm{H}), 3.75(\mathrm{~s}, 3 \mathrm{H}), 3.87(\mathrm{~s}, 3 \mathrm{H}), 5.57(\mathrm{dd}, J=9.2,4.9 \mathrm{~Hz}, 1 \mathrm{H}) ;{ }^{13} \mathrm{C}$ NMR $(100$ $\left.\mathrm{MHz}, \mathrm{CDCl}_{3}\right): 34.4,52.8,54.1,83.1,164.2,168.9$. HRMS (ESI): $[\mathrm{M}+\mathrm{Na}]^{+}$calcd for $\mathrm{C}_{6} \mathrm{H}_{9} \mathrm{NO}_{6} \mathrm{Na}$ : 214.0328, found 214.0322.

Diethyl 2-nitropentanedioate (7): General nitration procedure was used (1.0 $\mathrm{mL}(4.65 \mathrm{mmol})$ of diethyl 2-acetylpentanedioate (6) in $\left.\mathrm{CH}_{2} \mathrm{Cl}_{2}(11.9 \mathrm{~mL})\right)$. Quenching and deacylation procedure: for $10 \mathrm{~mL}$ of the collected solution $5 \mathrm{~g}$ of $\mathrm{MgSO}_{4}$ and $20 \mathrm{~mL} \mathrm{CH}_{2} \mathrm{Cl}_{2}$ were used, the reaction mixture was filtered and concentrated under reduced pressure. The residue was dissolved in $30 \mathrm{~mL} \mathrm{EtOH}$ and stirred 
overnight at room temperature. The solvent was removed under reduced pressure and the residue was purified by column chromatography ( $n$-hexane/ethyl acetate 9:1 $\rightarrow 2: 1 \mathrm{v} / \mathrm{v}$ ) to give compound 7 $(630 \mathrm{mg}, 75 \%)$ as a colorless oil. $\mathrm{R}_{\mathrm{f}}=0.49(n$-hexane/ethyl acetate $=3: 1 \mathrm{v} / \mathrm{v}) ;{ }^{1} \mathrm{H}$ spectrum matches with the literature data. ${ }^{31}{ }^{1} \mathrm{H}$ NMR $\left(400 \mathrm{MHz}, \mathrm{CDCl}_{3}\right): 1.26(\mathrm{dd}, \mathrm{J}=7.1,7.1 \mathrm{~Hz}, 3 \mathrm{H}), 1.30(\mathrm{dd}, \mathrm{J}=7.1$, 7.1 Hz, 3H), 2.39-2.61 (m, 4H), 4.15 (ddd, J = 7.1, 7.1, 7.1 Hz, 2H), 4.29 (ddd, J = 7.1, 7.1, 7.1 Hz, 2H), 5.27-5.32 (m, 1H); ${ }^{13} \mathrm{C}$ NMR (100 MHz, $\left.\mathrm{CDCl}_{3}\right):$ 14.0, 14.3, 25.4, 29.7, 61.1, 63.3, 86.8, 164.3, 171.6. HRMS (ESI): $[\mathrm{M}+\mathrm{Na}]^{+}$calcd for $\mathrm{C}_{9} \mathrm{H}_{15} \mathrm{NO}_{6} \mathrm{Na:} 256.0797$, found 256.0809 .

Ethyl 2-nitropropionate (9): General nitration procedure was used (ethyl 2-methylacetoacetate (8) purity $95 \%, 0.75 \mathrm{~mL}(5.30 \mathrm{mmol})$ of substrate 8 in $\left.\mathrm{CH}_{2} \mathrm{Cl}_{2}(13.25 \mathrm{~mL})\right)$. Quenching and deacylation procedure: for $10 \mathrm{~mL}$ of the collected solution $10 \mathrm{~g}$ of $\mathrm{MgSO}_{4}$ and $20 \mathrm{~mL} \mathrm{CH}_{2} \mathrm{Cl}_{2}$ were used, the reaction mixture was filtered and concentrated under reduced pressure. The residue was dissolved in $30 \mathrm{~mL} \mathrm{EtOH}$ and stirred for 3 hours at $80{ }^{\circ} \mathrm{C}$ (temperature of the oil bath). The solvent was removed under reduced pressure and the residue was purified by column chromatography ( $n$-hexane/ethyl acetate $15: 1 \rightarrow 10: 1 \mathrm{v} / \mathrm{v})$ to give compound $9(443 \mathrm{mg}, 59 \%)$ as a yellow oil. $\mathrm{R}_{\mathrm{f}}=0.43$ ( $n$-hexane/ethyl acetate $=5: 1 \mathrm{v} / \mathrm{V})$. Obtained NMR matches with the literature data. ${ }^{32}{ }^{1} \mathrm{H} \mathrm{NMR}\left(400 \mathrm{MHz}, \mathrm{CDCl}_{3}\right): 1.29$ $(\mathrm{t}, \mathrm{J}=7.1 \mathrm{~Hz}, 3 \mathrm{H}), 1.77(\mathrm{~d}, \mathrm{~J}=7.2 \mathrm{~Hz}, 3 \mathrm{H}), 4.26(\mathrm{q}, \mathrm{J}=7.2 \mathrm{~Hz}, 2 \mathrm{H}), 5.19(\mathrm{q}, \mathrm{J}=7.1 \mathrm{~Hz}, 1 \mathrm{H}) .{ }^{13} \mathrm{C} N M R$ $\left(100 \mathrm{MHz}, \mathrm{CDCl}_{3}\right): 14.0,15.8,63.1,83.3,165.2$.

Methyl 2-nitrobutanoate (11): General nitration procedure was used $(0.72 \mathrm{~mL}(5.04 \mathrm{mmol})$ of methyl 2ethylacetoacetate (10) in $\left.\mathrm{CH}_{2} \mathrm{Cl}_{2}(13.28 \mathrm{~mL})\right)$. Quenching and deacylation procedure: for $11 \mathrm{~mL}$ of the collected solution $10 \mathrm{~g}$ of $\mathrm{MgSO}_{4}$ and $20 \mathrm{~mL} \mathrm{CH}_{2} \mathrm{Cl}_{2}$ were used, the reaction mixture was filtered and concentrated under reduced pressure. The residue was dissolved in $30 \mathrm{~mL} \mathrm{MeOH}$ and stirred for 130 minutes at $65{ }^{\circ} \mathrm{C}$ (temperature of the oil bath). The solvent was removed under reduced pressure and the residue was purified by column chromatography ( $n$-hexane/ethyl acetate $10: 1 \rightarrow 7: 1 \mathrm{v} / \mathrm{V}$ ) to give compound $11(310 \mathrm{mg}, 53 \%)$ as a yellow oil. $\mathrm{R}_{\mathrm{f}}=0.45(n$-hexane/ethyl acetate $=5: 1 \mathrm{v} / \mathrm{v}) ;{ }^{1} \mathrm{H}$ NMR (400 MHz, $\left.\mathrm{CDCl}_{3}\right): 1.04$ (dd, J= 7.4, 7.4 Hz, 3H), 2.14-2.36 (m, 2H), 3.83 (s, 3H), 5.05 (dd, J= 9.3, 5.5 $\mathrm{Hz}, 1 \mathrm{H}) ;{ }^{13} \mathrm{C}$ NMR $\left(100 \mathrm{MHz}, \mathrm{CDCl}_{3}\right): 10.3,24.1,53.6,89.4,165.1$; HRMS (ESI): $[\mathrm{M}+\mathrm{Na}]^{+}$calcd for $\mathrm{C}_{5} \mathrm{H}_{9} \mathrm{NO}_{4} \mathrm{Na}: 170.0429$, found 170.0419, $[\mathrm{M}+\mathrm{K}]^{+}$calculated for $\mathrm{C}_{5} \mathrm{H}_{9} \mathrm{NO}_{4} \mathrm{~K}: 186.0169$, found 186.0159. Compound 11 was previously synthesized. ${ }^{9 b}$

7-Ethoxy-6-nitro-7-oxoheptanoic acid (13) and 7-ethoxy-6-(hydroxyimino)-7-oxoheptanoic acid (13a): General nitration procedure was used (ethyl 2-oxocyclohexanecarboxylate (12) purity 95\%, $0.85 \mathrm{~mL}$ 
(5.31 mmol) of substrate 12 in $\mathrm{CH}_{2} \mathrm{Cl}_{2}(13.15 \mathrm{~mL})$ ). Quenching and deacylation procedure: for $4 \mathrm{~mL}$ of the collected solution $5 \mathrm{~g}$ of $\mathrm{MgSO}_{4}$ and $20 \mathrm{~mL} \mathrm{CH} \mathrm{Cl}_{2}$ were used, the reaction mixture was filtered and concentrated under reduced pressure. The residue was dissolved in $30 \mathrm{ml}$ mixture of EtOH and water $(2: 1, v / v)$ and stirred overnight at $45{ }^{\circ} \mathrm{C}$ (temperature of the oil bath). The solvent was removed under reduced pressure and the residue was purified by column chromatography (DCM/MeOH 50:1 $\rightarrow$ $5: 2 \mathrm{v} / \mathrm{v}$ ) to give compound $13(275 \mathrm{mg}, 82 \%)$ as a yellow-green solid and compound $13 \mathrm{a}$ (33.4 $\mathrm{mg}$, $11 \%)$ as a yellow solid. Analytical data for compound 13: $R_{f}=0.30(D C M / M e O H=30: 1 \mathrm{v} / \mathrm{v}) ; \mathrm{mp} 57-$ $59{ }^{\circ} \mathrm{C} ;{ }^{1} \mathrm{H}$ NMR $\left(400 \mathrm{MHz}, \mathrm{CDCl}_{3}\right): 1.29(\mathrm{t}, \mathrm{J}=7.1 \mathrm{~Hz}, 3 \mathrm{H}), 1.40-1.49(\mathrm{~m}, 2 \mathrm{H})$ 1.66-1.74 (m, 2H), 2.10$2.19(\mathrm{~m}, 1 \mathrm{H}), 2.24-2.32(\mathrm{~m}, 1 \mathrm{H}), 2.36-2.39(\mathrm{~m}, 2 \mathrm{H}), 4.27(\mathrm{q}, J=7.1 \mathrm{~Hz}, 2 \mathrm{H}), 5.09(\mathrm{dd}, J=9.3,5.4 \mathrm{~Hz}$, 1H), 9-12 (br signal $\mathrm{COOH}) ;{ }^{13} \mathrm{C} \mathrm{NMR}\left(100 \mathrm{MHz}, \mathrm{CDCl}_{3}\right)$ 13.9, 23.8, 25.0, 29.9, 33.5, 63.2, 87.9, 164.5, 179.5; HRMS (ESI): [M+Na] ${ }^{+}$calcd for $\mathrm{C}_{9} \mathrm{H}_{15} \mathrm{NO}_{6} \mathrm{Na} 256.0797$, found 256.0796. Analytical data for compound 13a: $\mathrm{R}_{\mathrm{f}}=0.5(\mathrm{DCM} / \mathrm{MeOH}=15: 1 \mathrm{v} / \mathrm{v}) ; \mathrm{mp} 98-100{ }^{\circ} \mathrm{C} ;{ }^{1} \mathrm{H} \mathrm{NMR}\left(400 \mathrm{MHz}, \mathrm{CDCl}_{3}\right): 1.33$ $(\mathrm{t}, J=7.1 \mathrm{~Hz}, 3 \mathrm{H}), 1.62-1.71(\mathrm{~m}, 4 \mathrm{H}) 2.40(\mathrm{t}, J=7.1 \mathrm{~Hz}, 2 \mathrm{H}), 2.66(\mathrm{t}, J=7.2 \mathrm{~Hz}, 2 \mathrm{H}), 4.28(\mathrm{q}, J=7.1$ $\mathrm{Hz}, 2 \mathrm{H}), \mathrm{COOH}$ and $\mathrm{N}-\mathrm{OH}$ protons are not observed; ${ }^{13} \mathrm{C} \mathrm{NMR}\left(100 \mathrm{MHz}, \mathrm{CDCl}_{3}\right)$ 14.1, 24.5, 24.6, 25.3, , 33.7, 62.0, 152.0, 163.2, 179.1; HRMS (ESI): $[\mathrm{M}+\mathrm{Na}]^{+}$calcd for $\mathrm{C}_{9} \mathrm{H}_{15} \mathrm{NO}_{5} \mathrm{Na:} 240.0848$, found 240.0859.

Ethyl 2-nitrohexanoate (15): Nitric acid (90+\%, $16 \mu \mathrm{L} / \mathrm{min}, 0.343 \mathrm{mmol} / \mathrm{min})$ was mixed with sulfuric acid $(96 \%, 103 \mu \mathrm{L} / \mathrm{min}, 1.85 \mathrm{mmol} / \mathrm{min})$ at $10^{\circ} \mathrm{C}$ using a T-mixer. The resulting flow stream was passed through a $0.03 \mathrm{~mL}$ PTFE-tubing and mixed with the ethyl 2-acetylhexanoate (14) solution (1.0 mL (5.11 mmol) of substrate 14 in $\left.\mathrm{CH}_{2} \mathrm{Cl}_{2}(15 \mathrm{~mL}), 0.663 \mathrm{~mL} / \mathrm{min}, 0.212 \mathrm{mmol} / \mathrm{min}\right)$ using second T-mixer at the same temperature. The biphasic mixture was passed through $0.7 \mathrm{~mL}$ PTFE-tubing and collected in an Erlenmeyer flask containing stirred suspension of $\mathrm{MgSO}_{4}$ in $\mathrm{CH}_{2} \mathrm{Cl}_{2}$ (for $11 \mathrm{~mL}$ of the collected solution $5 \mathrm{~g}$ of $\mathrm{MgSO}_{4}$ and $20 \mathrm{~mL} \mathrm{CH} \mathrm{Cl}_{2}$ were used) at room temperature. The reaction mixture was filtered and concentrated under reduced pressure. The residue was dissolved in $30 \mathrm{~mL}$ $\mathrm{EtOH}$ and stirred overnight at room temperature. The solvent was removed under reduced pressure and the residue was purified by column chromatography ( $n$-hexane $\rightarrow n$-hexane/ethyl acetate, 100:0 $\rightarrow 9: 1 \mathrm{v} / \mathrm{v})$ to give compound $15(480 \mathrm{mg}, 72 \%)$ as a colorless oil. $R_{\mathrm{f}}=0.49$ ( $n$-hexane/ethyl acetate $=$ 2:1 v/v); ${ }^{1} \mathrm{H}$ NMR (400 MHz, $\left.\mathrm{CDCl}_{3}\right): 0.90(\mathrm{dd}, \mathrm{J}=6.9,6.9 \mathrm{~Hz}, 3 \mathrm{H}) ; 1.27(\mathrm{dd}, \mathrm{J}=7.1,7.1 \mathrm{~Hz}, 3 \mathrm{H})$, 1.32-1.42 (m, 4H), 2.05-2.15 (m, 1H), 2.18-2.31 (m, 1H), 4.25 (ddd, J = 7.1, 7.1, 7.1 Hz, 2H), 5.07 (dd, J = 9.4, 5.5 Hz, 1H); ${ }^{13} \mathrm{C}$ NMR (100 MHz, $\mathrm{CDCl}_{3}$ ): 13.8, 14.0, 22.1, 27.8, 30.1, 63.1, 88.3, 164.8; 
HRMS (ESI): $[\mathrm{M}+\mathrm{Na}]^{+}$calcd for $\mathrm{C}_{8} \mathrm{H}_{15} \mathrm{NO}_{4} \mathrm{Na}: 212.0899$, found 212.0887, $[\mathrm{M}+\mathrm{K}]^{+}$calculated for $\mathrm{C}_{8} \mathrm{H}_{15} \mathrm{NO}_{4} \mathrm{~K}: 228.0638$, found 228.0630 . Compound 15 was previously synthesized. ${ }^{15,33}$

Ethyl 2-chloro-2-nitroacetate (17): Nitric acid $(90+\%, 8 \mu \mathrm{L} / \mathrm{min}, 0.171 \mathrm{mmol} / \mathrm{min})$ was mixed with sulfuric acid $(96 \%, 52 \mu \mathrm{L} / \mathrm{min}, 0.923 \mathrm{mmol} / \mathrm{min})$ at $20{ }^{\circ} \mathrm{C}$ using a T-mixer. The resulting acid mixture was passed through a $0.03 \mathrm{~mL}$ PTFE-tubing and mixed with the ethyl 2-chloro-3-oxobutanoate (16) solution (substrate 16 purity $95 \%, 0.23 \mathrm{~mL}(1.6 \mathrm{mmol})$ substrate 16 in $\mathrm{CH}_{2} \mathrm{Cl}_{2}(7.77 \mathrm{~mL}), 0.332$ $\mathrm{mL} / \mathrm{min}, 0.066 \mathrm{mmol} / \mathrm{min}$ ) at the same temperature. The biphasic mixture was passed through $0.7 \mathrm{~mL}$ PTFE-tubing and collected in an Erlenmeyer flask containing stirred suspension of $\mathrm{MgSO}_{4}$ in $\mathrm{CH}_{2} \mathrm{Cl}_{2}$ (for $4 \mathrm{~mL}$ of the collected solution $5 \mathrm{~g}$ of $\mathrm{MgSO}_{4}$ and $20 \mathrm{~mL} \mathrm{CH} \mathrm{Cl}_{2}$ were used) at room temperature. The reaction mixture was filtered and concentrated under reduced pressure. The residue was dissolved in $10 \mathrm{ml} \mathrm{EtOH}$ and stirred overnight at room temperature. The solvent was gently removed under reduced pressure (room temperature) to give volatile compound 17 as a yellow oil (84\%, determined by ${ }^{1} \mathrm{H}$ NMR using mesitylene as internal standard). An analytically pure sample was obtained by column chromatography ( $n$-hexane/ethyl acetate $20: 1 \rightarrow 10: 1 \mathrm{v} / \mathrm{v}) . \mathrm{R}_{\mathrm{f}}=0.60(n-$ hexane/ethyl acetate $=2: 1 \mathrm{v} / \mathrm{v})$; Obtained ${ }^{1} \mathrm{H}$ NMR matches with the literature data. ${ }^{34}{ }^{1} \mathrm{H}$ NMR $(400$ $\left.\mathrm{MHz}, \mathrm{CDCl}_{3}\right): 1.36(\mathrm{t}, J=7.2 \mathrm{~Hz}, 3 \mathrm{H}), 4.39(\mathrm{q}, J=6.7 \mathrm{~Hz}, 2 \mathrm{H}), 6.23(\mathrm{~s}, 1 \mathrm{H}) ;{ }^{13} \mathrm{C} \mathrm{NMR}(100 \mathrm{MHz}$, $\left.\mathrm{CDCl}_{3}\right) 13.9,64.9,85.6,160.7$.

Ethyl 2-nitro-3-(4-nitrophenyl)propanoate (19), ethyl 2-nitro-3-(2-nitrophenyl)propanoate (20), and ethyl 2-(4-nitrobenzyl)-3-oxobutanoate (20a): Nitric acid (90+\%, $16 \mu \mathrm{L} / \mathrm{min}, 0.343 \mathrm{mmol} / \mathrm{min})$ was mixed with sulfuric acid $(96 \%, 103 \mu \mathrm{L} / \mathrm{min}, 1.852 \mathrm{mmol} / \mathrm{min})$ at $10{ }^{\circ} \mathrm{C}$ using a T-mixer. The resulting acid mixture was passed through a $0.03 \mathrm{~mL}$ PTFE-tubing and mixed with the ethyl 2-benzylacetoacetate (18) solution $\left(0.48 \mathrm{~mL}(2.26 \mathrm{mmol})\right.$ of substrate $\left.18 \mathrm{in} \mathrm{CH}_{2} \mathrm{Cl}_{2}(13.5 \mathrm{~mL}), 0.663 \mathrm{~mL} / \mathrm{min}, 0.106 \mathrm{mmol} / \mathrm{min}\right)$ at the same temperature. The biphasic mixture was passed through $0.7 \mathrm{~mL}$ PTFE-tubing and collected in an Erlenmeyer flask containing stirred suspension of $\mathrm{MgSO}_{4}$ in $\mathrm{CH}_{2} \mathrm{Cl}_{2}$ (for $11 \mathrm{~mL}$ of the collected solution $5 \mathrm{~g}$ of $\mathrm{MgSO}_{4}$ and $20 \mathrm{~mL} \mathrm{CH} \mathrm{Cl}_{2}$ were used) at room temperature. The reaction mixture was filtered and concentrated under reduced pressure. The residue was dissolved in $30 \mathrm{~mL} \mathrm{EtOH}$ and stirred overnight at $45{ }^{\circ} \mathrm{C}$. The solvent was removed under reduced pressure to give compound 19 (61\%), compound $20(16 \%)$ and compound 20a (7\%). (Due to the tedious purification procedure, the yields were determined by ${ }^{1} \mathrm{H}$ NMR using mesitylene as an internal standard). Analytically pure samples of compound $\mathbf{2 0}$ as a yellow oil were obtained using purification by column chromatography 
$(n$-hexane/DCM 2:1 $\rightarrow$ 1:5 v/v). Compound 20a was isolated as a yellow oil from the same column, however was unable to be separated from the impurities according to ${ }^{1} \mathrm{H} N M R$. An analytically pure sample of compound 19 was obtained by purification using HPLC Hex/iPrOH $(99: 1, v / v)$. Analytical data for compound 19: $\mathrm{R}_{\mathrm{f}}=0.33\left(n\right.$-hexane/DCM 1:4 v/v); ${ }^{1} \mathrm{H}$ NMR $\left(400 \mathrm{MHz}, \mathrm{CDCl}_{3}\right): 1.30(\mathrm{t}, J=7.1$ $\mathrm{Hz}, 3 \mathrm{H}), 3.59$ (dd, $J=14.8,5.3 \mathrm{~Hz}, 1 \mathrm{H}), 3.68(\mathrm{dd}, J=14.8,9.5 \mathrm{~Hz}, 1 \mathrm{H}), 4.31(\mathrm{q}, J=6.3 \mathrm{~Hz}, 2 \mathrm{H}), 5.36$ (dd, $J=9.4,5.7 \mathrm{~Hz}, 1 \mathrm{H}), 7.42(\mathrm{~d}, J=8.3 \mathrm{~Hz}, 2 \mathrm{H}), 8.20(\mathrm{~d}, J=8.2 \mathrm{~Hz}, 2 \mathrm{H}) ;{ }^{13} \mathrm{C} \mathrm{NMR}(100 \mathrm{MHz}$, $\left.\mathrm{CDCl}_{3}\right): 14.0,35.9,63.8,88.4,124.4,130.1,141.6,147.8$ 163.5; HRMS (ESI): $[\mathrm{M}+\mathrm{Na}]^{+}$calcd for $\mathrm{C}_{11} \mathrm{H}_{12} \mathrm{~N}_{2} \mathrm{O}_{6} \mathrm{Na}$ : 291.0593, found 291.0585. Analytical data for compound 20: $\mathrm{R}_{\mathrm{f}}=0.63$ ( $n$-hexane/DCM $1: 4 \mathrm{v} / \mathrm{v}) ;{ }^{1} \mathrm{H} \mathrm{NMR}\left(400 \mathrm{MHz}, \mathrm{CDCl}_{3}\right): 1.29(\mathrm{t}, J=6.9 \mathrm{~Hz}, 3 \mathrm{H}), 3.71(\mathrm{dd}, J=14.3,9.8 \mathrm{~Hz}, 1 \mathrm{H}), 3.90(\mathrm{dd}$, $J=14.4,4.9 \mathrm{~Hz}, 1 \mathrm{H}), 4.31(\mathrm{q}, J=7.1 \mathrm{~Hz}, 2 \mathrm{H}), 5.66(\mathrm{dd}, J=9.7,5.0 \mathrm{~Hz}, 1 \mathrm{H}), 7.36(\mathrm{~d}, J=7.6 \mathrm{~Hz}, 1 \mathrm{H})$, $7.50(\mathrm{dd}, J=7.8,7.8 \mathrm{~Hz}, 1 \mathrm{H}), 7.59(\mathrm{dd}, J=7.5,7.5 \mathrm{~Hz}, 1 \mathrm{H}), 8.11(\mathrm{~d}, J=8.2 \mathrm{~Hz}, 1 \mathrm{H}) ;{ }^{13} \mathrm{C}$ NMR $(100$ $\left.\mathrm{MHz}, \mathrm{CDCl}_{3}\right): 14.0,34.4,63.5,88.1,125.9,129.6,129.7,133.5,134.2,148.9,163.8$; HRMS-ESI: $[\mathrm{M}+\mathrm{Na}]^{+}$calcd for $\mathrm{C}_{11} \mathrm{H}_{12} \mathrm{~N}_{2} \mathrm{O}_{6} \mathrm{Na} 291.0593$ found 291.0591. Analytical data for compound 20a: Obtained NMR matches with the literature data. ${ }^{35} \mathrm{R}_{\mathrm{f}}=0.20$ ( $n$-hexane/DCM 1:4 v/v); ${ }^{1} \mathrm{H}$ NMR (400 $\left.\mathrm{MHz}, \mathrm{CDCl}_{3}\right): 1.22(\mathrm{t}, J=7.2 \mathrm{~Hz}, 3 \mathrm{H}), 2.24(\mathrm{~s}, 3 \mathrm{H}), 3.25(\mathrm{t}, J=7.6 \mathrm{~Hz}, 2 \mathrm{H}), 3.78(\mathrm{t}, J=8.0,1 \mathrm{H}), 4.12-$ $4.21(\mathrm{~m}, 2 \mathrm{H}), 7.36(\mathrm{~d}, J=8.8 \mathrm{~Hz}, 2 \mathrm{H}), 8.14(\mathrm{~d}, J=8.7 \mathrm{~Hz}, 2 \mathrm{H}) ;{ }^{13} \mathrm{C} N M R\left(100 \mathrm{MHz}, \mathrm{CDCl}_{3}\right): 14.2$, 29.7, 33.6, 60.8, 62.0, 123.9, 129.9, 146.2, 147.0, 168.6, 201.3.

Ethyl 2-nitroacetate (22): Nitric acid $(65 \%, 31 \mu \mathrm{L} / \mathrm{min}, 0.657 \mathrm{mmol} / \mathrm{min})$ was mixed with sulfuric acid $(96 \%, 110 \mu \mathrm{L} / \mathrm{min}, 1.972 \mathrm{mmol} / \mathrm{min})$ at $-5{ }^{\circ} \mathrm{C} \rightarrow-3{ }^{\circ} \mathrm{C}$ using a T-mixer $\left(\mathrm{EtOH} / \mathrm{N}_{2}\right.$ bath was used, volume of the loop before second T-mixer $0.5 \mathrm{~mL}$ ). The resulting acid mixture was passed through a $0.03 \mathrm{~mL}$ PTFE-tubing and mixed with the ethyl acetoacetate $(21)$ solution $(6.5 \mathrm{~mL}(49 \mathrm{mmol})$ of substrate 21 in $\left.\mathrm{CH}_{2} \mathrm{Cl}_{2}(42.5 \mathrm{~mL}), 0.4 \mathrm{~mL} / \mathrm{min}, 0.4 \mathrm{mmol} / \mathrm{min}\right)$ at the same temperature. The biphasic mixture was passed through $1.8 \mathrm{~mL}$ PTFE-tubing and collected in an Erlenmeyer flask containing stirred suspension of $\mathrm{MgSO}_{4}$ in $\mathrm{CH}_{2} \mathrm{Cl}_{2}\left(40.5 \mathrm{~mL}\right.$ of solution was collected, $21 \mathrm{~g}$ of $\mathrm{MgSO}_{4}$ was used: for $1 \mathrm{~mL}$ of the pumped $\mathrm{H}_{2} \mathrm{SO}_{4} 2 \mathrm{~g}$ of $\mathrm{MgSO}_{4}$ was used) at room temperature, the reaction mixture was filtered, dried over $\mathrm{Na}_{2} \mathrm{SO}_{4}$, treated with $\mathrm{EtOH}(1: 1 \mathrm{v} / \mathrm{V})$ and concentrated under reduced pressure $\left(30{ }^{\circ} \mathrm{C}\right)$. The residue was purified using Kugelrohr distillation at $100{ }^{\circ} \mathrm{C}, 11 \mathrm{mbar}$ to give compound $22(3.8 \mathrm{~g}, 70 \%)$ as a yellow oil. In addition, 22\% (determined by NMR using mesitylene as an internal standard) of 3,4-bis(ethoxycarbonyl)-1,2,5-oxadiazole 2-oxide (22b) ${ }^{4 \mathrm{c}}$ was observed. Analytical data for compound 22: ${ }^{1} \mathrm{H}$ NMR $\left(400 \mathrm{MHz}, \mathrm{CDCl}_{3}\right): 1.28$ (t, J = 7.2 Hz, 3H), 4.27 (q, J = 7.1 Hz, 2H), $5.14(\mathrm{~s}, 2 \mathrm{H}) ;{ }^{13} \mathrm{C}$ 
spectrum matches with the literature data. ${ }^{36}{ }^{13} \mathrm{C} \mathrm{NMR}\left(100 \mathrm{MHz}, \mathrm{CDCl}_{3}\right): 13.9,63.3,76.4,162.1$; HRMS (ESI): $[\mathrm{M}+\mathrm{Na}]^{+}$calcd for $\mathrm{C}_{4} \mathrm{H}_{7} \mathrm{NO}_{4} \mathrm{Na:}$ 156.0273, found 156.0252 .

$N, N$-Diethyl-2-nitroacetamide $\quad(\mathbf{2 4}), \quad N, N$-diethyl-2-(hydroxyimino)-3-oxobutanamide $\quad(\mathbf{2 4 a}), \quad$ 3,4bis(diethylcarbamoyl)-1,2,5-oxadiazole 2-oxide (24b): Nitric acid (90+\%, $8 \mu \mathrm{L} / \mathrm{min}, 0.171 \mathrm{mmol} / \mathrm{min}$ ) was mixed with sulfuric acid $(96 \%, 52 \mu \mathrm{L} / \mathrm{min}, 0.923 \mathrm{mmol} / \mathrm{min})$ at $10^{\circ} \mathrm{C}$ using a T-mixer. The resulting acid mixture was passed through a $0.03 \mathrm{~mL}$ PTFE-tubing and mixed with $\mathrm{N}, \mathrm{N}$-diethyl-3oxobutanamide (23) solution $\left(0.16 \mathrm{~mL}(1.01 \mathrm{mmol})\right.$ of substrate 23 in $\mathrm{CH}_{2} \mathrm{Cl}_{2}(4.84 \mathrm{~mL}), 0.332 \mathrm{~mL} / \mathrm{min}$, $0.066 \mathrm{mmol} / \mathrm{min}$ ) at the same temperature. The biphasic mixture was passed through $0.7 \mathrm{~mL}$ PTFEtubing and collected in an Erlenmeyer flask containing stirred suspension of $\mathrm{MgSO}_{4}$ in $\mathrm{CH}_{2} \mathrm{Cl}_{2}$ (for 4

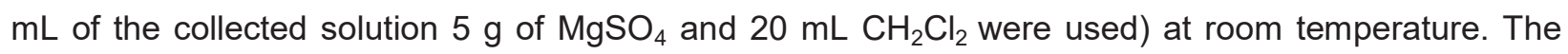
reaction mixture was filtered and concentrated under reduced pressure. Crude reaction mixture was purified by column chromatography ( $n$-hexane/ethyl acetate $5: 1 \rightarrow 1: 1 \mathrm{v} / \mathrm{V}$ ) to give compound 24 (68.7 $\mathrm{mg}, 54 \%)$ as a yellow oil, compound $24 \mathrm{~b}(23.4 \mathrm{mg}, 10 \%)$ as a yellow oil and compound $24 \mathrm{a}$ (16.7 mg, $11 \%)$ as a light peach clear solid. Analytical data for compound $24: R_{f}=0.19$ ( $n$-hexane/ethyl acetate $=$ 2:1 v/v); ${ }^{1} \mathrm{H}$ NMR $\left(400 \mathrm{MHz}, \mathrm{CDCl}_{3}\right): 1.17(\mathrm{t}, J=7.1 \mathrm{~Hz}, 3 \mathrm{H}), 1.23(\mathrm{t}, J=7.1 \mathrm{~Hz}, 3 \mathrm{H}), 3.24$ (q, $J=7.2$ $\mathrm{Hz}, 2 \mathrm{H}), 3.44$ (q, J = $7.1 \mathrm{~Hz}, 2 \mathrm{H}), 5.27$ (s, 2H); ${ }^{13} \mathrm{C}$ NMR (100 MHz, CD $\mathrm{OD}$ ): 12.9, 14.2, 42.0, 43.3, 78.3, 163.2; HRMS (ESI): $[\mathrm{M}+\mathrm{Na}]^{+}$calcd for $\mathrm{C}_{6} \mathrm{H}_{12} \mathrm{~N}_{2} \mathrm{O}_{3} \mathrm{Na:}$ 183.0746, found 183.0740. Analytical data for compound 24a: $R_{f}=0.07$ ( $n$-hexane/ethyl acetate $=2: 1 \mathrm{v} / \mathrm{v}$ ); Obtained NMR matches with literature data. ${ }^{37}{ }^{1} \mathrm{H}$ NMR (400 MHz, $\left.\mathrm{CDCl}_{3}\right): 1.12$ (t, $\left.J=7.0 \mathrm{~Hz}, 3 \mathrm{H}\right), 1.22$ (t, $\left.J=7.6 \mathrm{~Hz}, 3 \mathrm{H}\right), 2.39$ (s, 3H), 3.12 (q, $J=6.7 \mathrm{~Hz}, 2 \mathrm{H}), 3.52$ (q, $J=7.0 \mathrm{~Hz}, 2 \mathrm{H}), 11.64$ (s, 1H); ${ }^{13} \mathrm{C} \mathrm{NMR}\left(100 \mathrm{MHz}, \mathrm{CDCl}_{3}\right):$ 12.7, 14.0, 25.7, 39.3, 42.9, 152.4, 164.2, 195.2. Analytical data for compound 24b: $R_{f}=0.31$ ( $n$-hexane/ethyl acetate $=2: 1 \mathrm{v} / \mathrm{v}) ;{ }^{1} \mathrm{H}$ NMR $\left(400 \mathrm{MHz}, \mathrm{CDCl}_{3}\right): 1.18-1.32(\mathrm{~m}, 12 \mathrm{H}), 3.31(\mathrm{q}, J=7.2 \mathrm{~Hz}, 2 \mathrm{H}), 3.48-$ $3.55(\mathrm{~m}, 4 \mathrm{H}), 3.59$ (q, $J=7.1 \mathrm{~Hz}, 2 \mathrm{H}) ;{ }^{13} \mathrm{C}$ NMR (100 MHz, $\left.\mathrm{CDCl}_{3}\right):$ 12.6, 12.7, 14.4, 14.7, 40.5, 41.1, 43.3., 43.8, 111.5, 152.3, 154.8, 156.8; HRMS (ESI): $[\mathrm{M}+\mathrm{Na}]^{+}$calcd for $\mathrm{C}_{12} \mathrm{H}_{20} \mathrm{~N}_{4} \mathrm{O}_{4} \mathrm{Na}$ : 307.1382 , found 307.1372, $[\mathrm{M}+\mathrm{K}]^{+}$calcd for $\mathrm{C}_{12} \mathrm{H}_{20} \mathrm{~N}_{4} \mathrm{O}_{4} \mathrm{~K}: 323.1122$, found 323.1111.

4-Methoxy-4-oxobutanoic acid (26), methyl 4,5-dioxohexanoate (26a), methyl 4-(hydroxyimino)-5oxohexanoate (26b): General nitration procedure was used $(0.38 \mathrm{~mL}(2.16 \mathrm{mmol})$ of substrate 25 in $\left.\mathrm{CH}_{2} \mathrm{Cl}_{2}(5.62 \mathrm{~mL})\right)$. Quenching and deacylation procedure: for $4 \mathrm{~mL}$ of the collected solution $5 \mathrm{~g}$ of $\mathrm{MgSO}_{4}$ and $20 \mathrm{~mL} \mathrm{CH} \mathrm{Cl}_{2}$ were used, the reaction mixture was filtered and concentrated under reduced pressure. Crude was purified by column chromatography ( $n$-hexane /ethyl acetate $5: 1 \rightarrow 1: 1$ 
and then $\mathrm{DCM} \rightarrow \mathrm{DCM} / \mathrm{MeOH} 100: 1 \rightarrow 60: 1 \rightarrow 5: 1 \mathrm{v} / \mathrm{v})$ to give compound $26(65.4 \mathrm{mg}, 34 \%)$ as an yellow oil together with compound $\mathbf{2 6 a}(5.6 \mathrm{mg}, 3 \%$ ) as a yellow oil, and compound $\mathbf{2 6 b}(22.0 \mathrm{mg}, 9 \%)$ as a white amorphous solid. Additionally unreacted starting material was identified by ${ }^{1} \mathrm{H}$ NMR but was not isolated due to tedious purification procedure. Analytical data for compound 26: Obtained NMR matches with the literature data. ${ }^{38}{ }^{1} \mathrm{H} \mathrm{NMR}\left(400 \mathrm{MHz} \mathrm{CDCl}_{3}\right): 2.60-2.69(\mathrm{~m}, 4 \mathrm{H}), 3.69(\mathrm{~s}, 3 \mathrm{H}), 8.5-9.5$ (br, $\mathrm{COOH}) ;{ }^{13} \mathrm{C}$ NMR $\left(100 \mathrm{MHz}, \mathrm{CDCl}_{3}\right): 28.8,29.1,52.1,172.8,178.4$. Analytical data for compound 26a: $\mathrm{R}_{\mathrm{f}}=0.4(n$-hexane/ethyl acetate $=4: 1 \mathrm{v} / \mathrm{v}) ;{ }^{1} \mathrm{H}$ NMR $\left(600 \mathrm{MHz}, \mathrm{CDCl}_{3}\right): 2.36(\mathrm{~s}, 3 \mathrm{H}), 2.66(\mathrm{t}, \mathrm{J}=6$ $\mathrm{Hz} 2 \mathrm{H}$ ), 3.03 (t, J = $6 \mathrm{~Hz}, 2 \mathrm{H}), 3.69$ (s, 3H); ${ }^{13} \mathrm{C}$ NMR (151 MHz, $\mathrm{CDCl}_{3}$ ): 23.8, 27.8, 30.9, 52.1, 172.9, 197.1, 197.6; HRMS (ESI): $[\mathrm{M}+\mathrm{Na}]^{+}$calcd for $\mathrm{C}_{7} \mathrm{H}_{10} \mathrm{O}_{4} \mathrm{Na}$ : 181.0477, found 181.0478. Compound 26a was previously synthesized. ${ }^{39}$ Analytical data for compound $26 \mathrm{~b}: \mathrm{R}_{\mathrm{f}}=0.37(\mathrm{DCM} / \mathrm{MeOH}=30: 1 \mathrm{v} / \mathrm{v}) ; ;$ ${ }^{1} \mathrm{H}$ NMR $\left(400 \mathrm{MHz}, \mathrm{CDCl}_{3}\right): 2.37(\mathrm{~s}, 3 \mathrm{H}), 2.52(\mathrm{t}, J=7.8 \mathrm{~Hz}, 2 \mathrm{H}), 2.84(\mathrm{t}, J=7.7 \mathrm{~Hz}, 2 \mathrm{H}), 3.67(\mathrm{~s}, 3 \mathrm{H})$, 7.89 (s, 1H); ${ }^{13} \mathrm{C}$ NMR (100 MHz, $\left.\mathrm{CDCl}_{3}\right): 18.2,25.4,30.2,52.0,158.8,173.2,196.7$; HRMS (ESI): $[\mathrm{M}+\mathrm{Na}]^{+}$calcd for $\mathrm{C}_{7} \mathrm{H}_{11} \mathrm{NO}_{4} \mathrm{Na}$ : 196.0586, found 196.0579, $[\mathrm{M}+\mathrm{K}]^{+}$calcd for $\mathrm{C}_{7} \mathrm{H}_{11} \mathrm{NO}_{4} \mathrm{~K} 212.0325$, found 212.0322 .

6-Ethoxy-5,6-dioxohexanoic acid (28), 6-ethoxy-5-(hydroxyimino)-6-oxohexanoic acid (31), 6-ethoxy-5nitro-6-oxohexanoic acid (28b): General nitration procedure was used $(0.75 \mathrm{~mL}(5.06 \mathrm{mmol})$ of ethyl 2-oxocyclopentanecarboxylate (27) in $\left.\mathrm{CH}_{2} \mathrm{Cl}_{2}(13.25 \mathrm{~mL})\right)$. Quenching and deacylation procedure: for $11 \mathrm{~mL}$ of the collected solution $10 \mathrm{~g}$ of $\mathrm{MgSO}_{4}$ and $20 \mathrm{~mL} \mathrm{CH} \mathrm{Cl}_{2}$ were used, the reaction mixture was filtered and concentrated under reduced pressure. Analysis of crude ${ }^{1} \mathrm{H}$ NMR revealed formation of 6ethoxy-5,6-dioxohexanoic acid (28) with the $61 \%$ yield determined by ${ }^{1} \mathrm{H}$ NMR using mesitylene as internal standard. Presumably ethyl 1-nitro-2-oxocyclopentanecarboxylate (29) was formed, as suggested by the ${ }^{1} \mathrm{H}$ NMR spectrum $\left({ }^{1} \mathrm{H}\right.$ NMR $\left(400 \mathrm{MHz}, \mathrm{CDCl}_{3}\right)$ : 2.05-2.13 (m, 2H), 2.53-2.61 (m, 2H), $2.81(\mathrm{dt}, J=14.5,7.3 \mathrm{~Hz}, 1 \mathrm{H}), 2.96(\mathrm{dt}, J=14.0,6.8 \mathrm{~Hz}, 1 \mathrm{H})$, peaks corresponding to EtO-group are overlapping with EtO-group of another compound) which, upon standing, spontaneously undergoes a ring-opening reaction with atmospheric water to give compound $\mathbf{2 8} \mathbf{b}$. The residue was purified by column chromatography ( $n$-hexane/ethyl acetate $15: 1 \rightarrow 10: 1$ and then DCM/MeOH 60:1 $\rightarrow 15: 1 \mathrm{v} / \mathrm{v})$ to give compound 28 (353 $\mathrm{mg}, 47 \%)$ as a yellow oil, oxime $31(42.2 \mathrm{mg}, 5 \%)$ as a white solid and compound $\mathbf{2 8 b}$ (33 mg, 4\%) as a white solid. Analytical data for compound 28 : $R_{f}=0.45$ $(\mathrm{DCM} / \mathrm{MeOH}=15: 1 \mathrm{~V} / \mathrm{V} / \mathrm{V})$; Analytical data for the compound 28 matches with the literature data. ${ }^{40}{ }^{1} \mathrm{H}$ $\operatorname{NMR}\left(400 \mathrm{MHz}, \mathrm{CDCl}_{3}\right.$ ): 1.37 (t, $J=7.1 \mathrm{~Hz}, 3 \mathrm{H}$ ), 1.97 (quin, $J=7.2 \mathrm{~Hz}, 2 \mathrm{H}$ ), 2.44 (t, $J=7.2 \mathrm{~Hz}, 2 \mathrm{H}$ ), $2.95(\mathrm{t}, J=7.1 \mathrm{~Hz}, 2 \mathrm{H}), 4.32(\mathrm{q}, J=7.1 \mathrm{~Hz}, 2 \mathrm{H}), 9-11$ (br signal $\mathrm{COOH}) ;{ }^{13} \mathrm{C}$ NMR $\left(100 \mathrm{MHz}, \mathrm{CDCl}_{3}\right)$ : 
14.0, 17.9, 32.6, 38.2, 62.6, 160.8, 179.2, 193.7. Analytical data for compound 31: $R_{f}=0.31$

$(\mathrm{DCM} / \mathrm{MeOH}=15: 1 \mathrm{v} / \mathrm{v} / \mathrm{v}) ; \mathrm{mp} 106-108{ }^{\circ} \mathrm{C} ;{ }^{1} \mathrm{H}$ NMR: $\left(400 \mathrm{MHz}, \mathrm{CDCl}_{3}\right): 1.35(\mathrm{t}, \mathrm{J}=7.1 \mathrm{~Hz}, 3 \mathrm{H}), 1.96$ (p, J = 6.9 Hz, 2H), $2.45(\mathrm{t}, J=6.9 \mathrm{~Hz}, 2 \mathrm{H}), 2.73(\mathrm{t}, J=7.0 \mathrm{~Hz}, 2 \mathrm{H}), 4.30$ (q, J = 7.1 Hz, 2H), 10-12 (br signal $\mathrm{COOH}$ ), signal for $\mathrm{N}-\mathrm{OH}$ proton is not observed; ${ }^{13} \mathrm{C} \mathrm{NMR}\left(100 \mathrm{MHz}, \mathrm{CDCl}_{3}\right)$ 14.1, 21.0, 24.3, 33.6, 62.1, 151.9, 163.2, 178.2; HRMS (ESI): $[\mathrm{M}+\mathrm{Na}]^{+}$calcd for $\mathrm{C}_{8} \mathrm{H}_{13} \mathrm{NO}_{5} \mathrm{Na}$ 226.0691, found 226.0686. Analytical data for compound 28b: $\mathrm{R}_{\mathrm{f}}=0.48(\mathrm{DCM} / \mathrm{MeOH}=15: 1 \mathrm{v} / \mathrm{v} / \mathrm{v}) ; \mathrm{mp} 47-49{ }^{\circ} \mathrm{C} ;{ }^{1} \mathrm{H}$ NMR (400 MHz, $\left.\mathrm{CDCl}_{3}\right): 1.31(\mathrm{dd}, J=7.1,7.1 \mathrm{~Hz}, 3 \mathrm{H}), 1.67-1.80(\mathrm{~m}, 2 \mathrm{H}), 2.18-2.27(\mathrm{~m}, 1 \mathrm{H}), 2.29-$ $2.39(\mathrm{~m}, 1 \mathrm{H}), 2.46(\mathrm{t}, J=7.1 \mathrm{~Hz}, 2 \mathrm{H}), 4.29(\mathrm{ddd}, J=7.1,7.1,7.1 \mathrm{~Hz}, 2 \mathrm{H}), 5.12(\mathrm{dd}, J=9.3,5.5 \mathrm{~Hz}$, 1H), 10-12 (br signal COOH); ${ }^{13} \mathrm{C}$ NMR (100 MHz, $\left.\mathrm{CDCl}_{3}\right)$ 14.0, 20.8, 29.5, 33.0, 63.3, 87.8, 164.4, 178.7; HRMS (ESI): [M-H] $]^{+}$calcd for $\mathrm{C}_{8} \mathrm{H}_{12} \mathrm{NO}_{6}: 218.0665$, found 218.0686.

\section{Supporting Information}

${ }^{1} \mathrm{H}$ and ${ }^{13} \mathrm{C}$ NMR spectra for all new compounds, optimization experiments to determine minimum amount of desiccant needed for the quenching procedure

\section{Author information}

\section{Notes}

The authors declare no competing financial interest.

\section{Acknowledgments}

We gratefully acknowledge the financial support of the Max Planck Society. We also thank Fabian Klautzsch and Sebastian Schmid for recording high-resolution mass spectra.

\section{References}

(1) (a) Kislyi, V. V.; Samet, A. V.; Semenov, V. V. Curr. Org. Chem. 2001, 5, 553-570.(b) Tietze, L. F.; Schneider, C. In Encyclopedia of Reagents for Organic Synthesis; John Wiley \& Sons, Ltd: 2001.(c) Shipchandler, M. Synthesis 1979, 666-686.

(2) Goumont, R.; Magnier, E.; Kizilian, E.; Terrier, F. J. Org. Chem. 2003, 68, 6566-6570.

(3) (a) Ji, C.-B.; Liu, Y.-L.; Cao, Z.-Y.; Zhang, Y.-Y.; Zhou, J. Tetrahedron Lett. 2011, 52, 6118-6121.(b) Luzzio, F. A. Tetrahedron 2001, 57, 915-945.(c) Parise, L.; Pelagalli, A.; Pellacani, L.; Sciubba, F.; Vergari, M. C.; Fioravanti, S. J. Org. Chem. 2016, 81, 2864-2874.(d) Zhang, S.; Xu, K.; Guo, F.; Hu, Y.; Zha, Z.; Wang, Z. Chem. Eur. J. 2014, 20, 979-982.(e) Zhou, Y.; Liu, Q.; Gong, Y. Tetrahedron Lett. 
2013, 54, 3011-3014.(f) Aginagalde, M.; Bello, T.; Masdeu, C.; Vara, Y.; Arrieta, A.; Cossio, F. P. J. Org. Chem. 2010, 75, 7435-7438.(g) Lin, S.; Li, M.; Dong, Z.; Liang, F.; Zhang, J. Org. Biomol. Chem. 2014, 12, 1341-1350.(h) Dauzonne, D.; Royer, R. Synthesis 1983, 836-837.(i) Xu, J.; Ai, J.; Liu, S.; Peng, X.; Yu, L.; Geng, M.; Nan, F. Org. Biomol. Chem. 2014, 12, 3721-3734.

(4) (a) Gangadhara Chary, R.; Rajeshwar Reddy, G.; Ganesh, Y. S. S.; Vara Prasad, K.; Raghunadh, A.; Krishna, T.; Mukherjee, S.; Pal, M. Adv. Synth. Catal. 2014, 356, 160-164.(b) Chen, K.-P.; Chen, Y.-J.; Chuang, C.-P. Eur. J. Org. Chem. 2010, 2010, 5292-5300.(c) Trogu, E.; Cecchi, L.; De Sarlo, F.; Guideri, L.; Ponticelli, F.; Machetti, F. Eur. J. Org. Chem. 2009, 5971-5978.(d) Guideri, L.; De Sarlo, F.; Machetti,

F. Chem. Eur. J. 2013, 19, 665-677.(e) Baranov, M. S.; Yampolsky, I. V. Tetrahedron Lett. 2013, 54, 628-629.(f) Nakamura, S.; Sugimoto, H.; Ohwada, T. J. Am. Chem. Soc. 2007, 129, 1724-1732.

(5) (a) Xu, X.; Lu, H.; Ruppel, J. V.; Cui, X.; Lopez de Mesa, S.; Wojtas, L.; Zhang, X. P. J. Am. Chem. Soc. 2011, 133, 15292-15295.(b) Moreau, B.; Alberico, D.; Lindsay, V. N. G.; Charette, A. B. Tetrahedron 2012, 68, 3487-3496.(c) Moreau, B.; Charette, A. B. J. Am. Chem. Soc. 2005, 127, 18014-18015.(d) Charette, A. B.; Wurz, R. P.; Ollevier, T. Helv. Chim. Acta 2002, 85, 4468-4484.(e) Charette, A. B.; Wurz, R. J. Mol. Catal. A: Chem. 2003, 196, 83-91.

(6) (a) So, S. S.; Mattson, A. E. J. Am. Chem. Soc. 2012, 134, 8798-8801.(b) Yang, T.; Zhuang, H.; Lin, X.; Xiang, J.-N.; Elliott, J. D.; Liu, L.; Ren, F. Tetrahedron Lett. 2013, 54, 4159-4163.

(7) Metz, A. E.; Kozlowski, M. C. J. Org. Chem. 2013, 78, 717-722.

(8) (a) Young, A. J.; White, M. C. J. Am. Chem. Soc. 2008, 130, 14090-14091.(b) Chen, Z.; Morimoto, H.; Matsunaga, S.; Shibasaki, M. J. Am. Chem. Soc. 2008, 130, 2170-2171.(c) Singh, A.; Yoder, R. A.; Shen, B.; Johnston, J. N. J. Am. Chem. Soc. 2007, 129, 3466-3467.(d) He, L.; Srikanth, G. S. C.; Castle, S. L. J. Org. Chem. 2005, 70, 8140-8147.(e) Singh, A.; Johnston, J. N. J. Am. Chem. Soc. 2008, 130, 58665867.(f) Ram, S.; Ehrenkaufer, R. E. Synthesis 1986, 133-135.

(9) (a) Reddy, G. R.; Mukherjee, D.; Chittoory, A. K.; Rajaram, S. Org. Lett. 2014, 16, 5874-5877.(b) Lehr, F.; Gonnermann, J.; Seebach, D. Helv. Chim. Acta 1979, 62, 2258-2275.

(10) (a) Zen, S.; Koyama, M.; Koto, S. In Org. Synth.; John Wiley \& Sons, Inc.: 2003.(b) Matthews, V.; Kubler, D. J. Org. Chem. 1960, 25, 266-268.

(11) (a) Lyttle, D. A.; Weisblat, D. I. J. Am. Chem. Soc. 1947, 69, 2118-2119.(b) Snyder, B. H. R.; Katz, L. J. Am. Chem. Soc. 1947, 69, 3140-3142.(c) Genet, J. P.; Ferround, D. Tetrahedron Lett. 1984, 25, 35793582.(d) Fiandanese, V.; Naso, F.; Scilimati, A. Tetrahedron Lett. 1984, 25, 1187-1190.(e) Metz, A. E.; Berritt, S.; Dreher, S. D.; Kozlowski, M. C. Org. Lett. 2012, 14, 760-763.

(12) (a) Kornblum, N.; Chalmers, M. E.; Daniels, R. J. Am. Chem. Soc. 1955, 77, 6654-6655.(b) Kornblum, N.; Blackwood, R. K.; Powers, J. W. J. Am. Chem. Soc. 1957, 79, 2507-2509.

(13) Kornblum, N.; Weaver, W. M. J. Am. Chem. Soc. 1958, 80, 4333-4337.

(14) Simchen, G. Liebigs Ann. Chem. 1979, 1979, 628-638.

(15) Carmeli, M.; Rozen, S. J. Org. Chem. 2006, 71, 4585-4589.

(16) Sifniades, S. J. Org. Chem. 1975, 40, 3562-3566.

(17) Kislyi, V. P.; Laikhter, A. L.; Ugrak, B. I.; Semenov, V. V. Russ. Chem. Bull. 1994, 43, 70-74.

(18) Laikhter, A. L.; Kislyi, V. P.; Semenov, V. V. Mendeleev Commun. 1993, 3, 20-21.

(19) Nakaike, Y.; Taba, N.; Itoh, S.; Tobe, Y.; Nishiwaki, N.; Ariga, M. Bull. Chem. Soc. Jpn. 2007, 80, 2413-2417.

(20) Hessel, V.; Kralisch, D.; Kockmann, N.; Noël, T.; Wang, Q. ChemSusChem 2013, 6, 746-789.

(21) Kulkarni, A. A. Beilstein J. Org. Chem. 2014, 10, 405-424.

(22) (a) Brocklehurst, C. E.; Lehmann, H.; La Vecchia, L. Org. Process Res. Dev. 2011, 15, 1447-1453.(b) Yu, Z.; Zhou, P.; Liu, J.; Wang, W.; Yu, C.; Su, W. Org. Process Res. Dev. 2016, 20, 199-203.

(23) See Supporting Information for details. The product yield does not depend on the duration of the stirring with desiccant, even after $3 \mathrm{~h}$ stirring of the reaction mixture with magnesium sulfate the yield of the reaction didn't change.

(24) Yield determined by $1 \mathrm{H}$ NMR using mesytline as internal standard due to the volatility of the product.

(25) See Experimental Section for details

(26) Simmons, T.; Kreuz, K. J. Org. Chem. 1968, 33, 836-837.

(27) See Experimental Section for details 
(28) Pinnick, H. W. In Organic Reactions; John Wiley \& Sons, Inc.: 2004.

(29) Gottlieb, H. E.; Kotlyar, V.; Nudelman, A. J. Org. Chem. 1997, 62, 7512-7515.

(30) Zen, S.; Kaji, E. Org. Synth. 1977, 57, 60.

(31) Niyazymbetov, M. E.; Evans, D. H. J. Org. Chem. 1993, 58, 779-783.

(32) Kim, S.-U.; Liu, Y.; Nash, K. M.; Zweier, J. L.; Rockenbauer, A.; Villamena, F. A. J. Am. Chem. Soc. 2010, 132, 17157-17173.

(33) Feuer, H.; Monter, R. P. J. Org. Chem. 1969, 34, 991-995.

(34) (a) Martynov, I. V.; Zavel'skii, V. O.; Kovalenko, S. V.; Yurtanov, A. I. Izv. Akad. Nauk SSSR, Ser. khim. 1982, 1029-1033.(b) Martynov, I. V.; Zavel'skii, V. O.; Kovalenko, S. V.; Fetisov, V. I.; Yurtanov, A. I. Dokl. Akad. Nauk SSSR 1983, 152-156.

(35) Sin, I.; Kang, C. S.; Bandara, N.; Sun, X.; Zhong, Y.; Rogers, B. E.; Chong, H.-S. Biorg. Med. Chem. 2014, 22, 2553-2562.

(36) Takeuchi, Y.; Itoh, N.; Koizumi, T.; Yamagami, C.; Takeuchi, Y. Magn. Reson. Chem. 1992, 30, 5864.

(37) Paine, J. B.; Brough, J. R.; Buller, K. K.; Erikson, E. E.; Dolphin, D. J. Org. Chem. 1987, 52, 39933997.

(38) Sedelmeier, J.; Ley, S. V.; Baxendale, I. R.; Baumann, M. Org. Lett. 2010, 12, 3618-3621.

(39) Greene, B.; Lewis, K. Aust. J. Chem. 1968, 21, 1845-1852.

(40) Schröder, K.; Join, B.; Amali, A. J.; Junge, K.; Ribas, X.; Costas, M.; Beller, M. Angew. Chem. Int. Ed. 2011, 50, 1425-1429.

\section{Table of contents graphic}

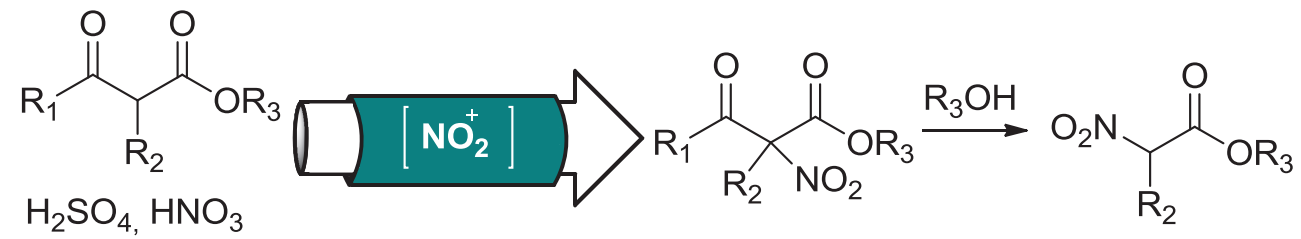

